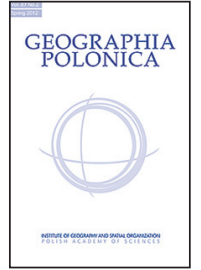

\title{
THE TIMBERLINE AS RESULT OF THE INTERACTIONS AMONG FOREST, ABIOTIC ENVIRONMENT AND HUMAN ACTIVITY IN THE BABIA GÓRA MT., WESTERN CARPATHIANS
}

\author{
Ryszard J. Kaczka ${ }^{1}$ Barbara Czajka1 ${ }^{1}$ Adam Łajczak ${ }^{2} \bullet$ \\ Jerzy Szwagrzyk ${ }^{3}$ - Paweł Nicia ${ }^{4}$ \\ ${ }^{1}$ Faculty of Earth Sciences \\ University of Silesia in Katowice \\ Będzińska 60, 41-200 Sosnowiec: Poland \\ e-mails: ryszard.kaczka@us.edu.pl • \\ barczajka@wp.pl \\ ${ }^{2}$ Institute of Geography \\ Pedagogical University of Krakow \\ Podchorażych 2, 30-084 Krakow: Poland \\ e-mail: alajczak@o2.pl \\ ${ }^{3}$ Department of Forest Biodiversity, \\ Institute of Forest Ecology and Silviculture \\ University of Agriculture in Kraków \\ Al. 29 listopada 46, 31-425 Krakow: Poland \\ e-mail: rlszwagr@cyf-kr.edu.pl \\ ${ }^{4}$ Department of Soil Science and Soil Protection \\ University of Agriculture in Krakow \\ Mickiewicza 21, 31-120 Krakow: Poland \\ e-mail: rrnicia@cyf-kr.edu.pl
}

\begin{abstract}
The character and main natural and anthropogenic factors driving the timberline on the Babia Góra Mt. was discussed. The model of Holtmeier (2009) was modified to describe the functioning of the local timberline. Originating in a geological structure, the asymmetric shape of the ridge of the Babia Góra Mt. created consequences for most of the components of the environment of the timberline. This main stationary factor influence all the others including the differences of local climate, soil development and human activity. The long history of direct impact of land use, grazing and logging and recent indirect influences (air pollution and climate warming) control the present character of the timberline.
\end{abstract}

\section{Key words}

timberline • Carpathians • the Babia Góra Mt. • grazing • spatial and temporal dynamics of timberline

\section{Introduction}

The timberline (TE), often a smooth transition (ecotone) between a forest and open space, is one of the clearest and most discernible border in nature (Troll 1973). The timberline is an important boundary in a mountain environment that separates two areas that differ in the functioning of biotic and abiotic components - the forest and the alpine zone (Kotarba \& Starkel 1972; Brown 1994; Walsh et al. 1994).

The major determinant at a macro scale that restricts the existence of forest at a given 
altitude is the temperature during the growing season (Tranquillini 1979; Holtmeier 2009; Körner 2012). On the meso and micro scales, the course of the timberline is further modified by a variety of environmental factors and processes. Therefore it is vital to replace the concept of the timberline, which is a reflection of isotherms (e.g. an annual temperature of $2^{\circ} \mathrm{C}$, according to Hess 1965) with the more complex line of the actual, empirical timberline. The course of this line is the result of all of the biotic, abiotic and anthropogenic factors at a certain time (Holtmeier 2009; Körner 2012). Locally, a significant role can be played by, for example, regularly blowing winter winds that carry ice crystals and contribute to the physical deterioration of the assimilation apparatus (Smith et al. 2003). As a result, trees become dwarfs and grow like shrubs, thus not creating a forest. The impact of wind on lowering the timberline strongly depends on topography; as a rule, it can be seen in the specific types of trees that grow under the overwhelming influence of the wind (Myczkowski 1964). All these do not, however, mean a contradiction between global models and local dependencies that determine the course of the timberline. The literature does not describe any case in which the forest exists above the climatic limits (Tranquillini 1979; Holtmeier 2009; Körner 2012). All of the factors that cause deviations in the course of the empirical timberline from a specified isotherm act towards lowering the range of the forest. The character as well as the intensity of the factors controlling the timberline vary in time and space posing one of the main challenges for the conceptual models that describe the functioning of the timberline. Another challenge is related to the synergistic or antagonistic interaction of the factors that are responsible for the condition of the upper subalpine forest. This applies mainly to stationary factors such as geology, topography and soil conditions and dynamic factors such as avalanches (Bebi et al. 2009), extreme geomorphological events (debris flows, rockfalls) (Rączkowska 2006), weather factors (windfalls) and ecological factors (fires, insect outbreaks)
(Ayres \& Lombardero 2000). Previous studies considered climate to also be a stationary factor but now more and more researchers stress the variability of this factor and its dependence on human impact (Sitko \& Troll 2008). The upward shift of the timberline as a result of global climate change has already been abundantly covered in the literature (Kullman 2002; Dullinger et al. 2004). The human activities such as logging, grazing and developing tourist infrastructure directly alter the course and nature of the timberline (Weisberg et al. 2013).

The formation of timberline as result of the balance between a forest and the open space above it is the result of the long evolution of the landscape in the Holocene. Whereas the recent location and character of the timberline is the consequence of the interactions of natural factors as well as increasing of human impact. In the last few hundred years, human activity has dominated over the natural factors (Slaymaker \& Embleton-Hamann 2009; Holtmeier 2009; Körner 2012). This is not a one-way process. At various times in the twentieth century, legal protection has been established in many mountain areas, which resulted in the reduction of direct human impact and led to spontaneous or assisted restoration of the timberline ecotone. However, at the same time, indirect human impacts such air pollution, acid rain, the destruction of ozone layer and the greenhouse effect (IPCC 2013) increased in importance. One can hypothesize that most modern transformations of the timberline mainly reflect changes in the intensity and character of the human impact.

Among the existing conceptual models that describe the complex nature of the relationships between the timberline, the natural drivers and human impact, the most applicable one seems to be that presented by Holtmeier (2009) who comprehensively described the timberline, taking into account its course, appearance and ecological characteristics.

The Holtmeier model (2009) also includes the variability in time of natural factors such as climate as well as biotic interactions. It considers the local topography, soil and 
composition of tree species to be stable, although the last factor requires that the stage of succession be considered. Among the tree species that occur in subalpine forest, some shifts in their ranges and above all, changes in the participation, changes in the composition of plant communities are possible. By contrast, the species pool in the timberline ecotone remains more or less constant. Recent and past human influences play important roles in this model. Particular attention is paid to the consequences of past human activity. It is this factor that the quoted author sees as the main condition for the state of the recent timberline. The only drawback of the model seems to be its disregard of natural abiotic processes (e.g., avalanches, debris flows, landslides, strong winds), which can strongly modify all three of the features of the timberline.

\section{Babia Góra - a unique and typical study site}

Babia Góra, $1725 \mathrm{~m}$ a.s.l. is the highest peak in the Western Beskidy with the shape of $10 \mathrm{~km}$ long W-E aligned monocline. Thus the northern slope is steep with comparison with proportionately gentle southern slope. The relative height of Babia Góra is $1100 \mathrm{~m}$ and the ridge is 200 to $800 \mathrm{~m}$ higher than the neighboring ridges. Above $1000 \mathrm{~m}$ a.s.l., the area is formed of Magura sandstone, while in lower elevations the main bedrock is the less resistant sub-Magura layers. Deep-seated landslides have modified the slopes and debris flows and snow avalanches have also shaped the upper part of the northern slope (Łajczak et al. 2014).

The Babia Góra Mt. can be distinguished from the other ridges from the region by fully developed vegetation zones including those above the timberline (Obrębska-Starkel 2004; Parusel et al. 2004). The above mentioned features indicate the unique position of Babia Góra within the Western Beskidy Mountains. Other features of the area are typical for the Western Carpathian mountain range. This refers to the geological (lithological) structure, which is similar to the whole area of the Western Beskidy, the most important features of which are the rippled layers of sandstones and shales and the synclinal or monoclinal nature of the ridges (Alexandrowicz 2004). A rocky substrate is associated with mountain soils, which at the high-altitude timberline are strongly skeletal and, in some areas, are in the early stages of development (Miechówka et al. 2004). The Babia Góra forests are largely remnants of the primeval Carpathian Forest. This particularly applies to the subalpine spruce forests the vast majority of which have retained their natural character. Grazing could have contributed, to the removal of dwarf mountain pine, lowering the timberline, and to the cutting of single trees in the subalpine forest belt (Łajczak \& Lamorski 2015). However, the extensive clearcuts, which largely transformed the landscape of the Babia Góra forests in the late nineteenth and early twentieth centuries, have been limited in the subalpine forest belt to relatively small areas (Holeksa et al. 2004). Despite the intense human pressure (especially grazing), the forest in the subalpine zone, have preserved their natural character in many areas (Parusel et al. 2004).

Sound information on the functioning of the timberline on Babia Góra will allow us to obtain a better understanding of the mechanisms that control the mountain landscape in the Western Carpathians. Old spruce stands are a particular feature of Babia Góra as they predominant in timberline zone. In the rest of this zone, spruce forests have been under the direct or indirect influence of grazing but now the forests are in the process of spontaneous re-naturalization. This creates a unique opportunity to study the natural and the semi-natural dynamics of the timberline in this part of the Carpathians.

\section{Timberline ecotone at Babia Góra Mt.}

From all the main types of timberline described by Sokołowski (1928), Plesník (1971) and Zientarski (1985), the topographic one is currently the most common (Czajka et al. 
$2015 a, c)$. The average altitude of the timberline reaches $1370 \mathrm{~m}$ a.s.l., with the highest location at $1508 \mathrm{~m}$ a.s.l. on the southern slope near Rabčicka hol'á glade (Slovakia), and the lowest location at $1106 \mathrm{~m}$ a.s.l. on the northern slope of the Mała Babia Mt. (Fig. 1). The altitudinal variability of the timberline is similar to the other mountain ranges within the Carpathian Arc (Czajka et al. 2015b). The spatiotemporal dynamics of the timberline based on the comparison of orthophotomaps from 1964 and 2009 (Czajka \& Kaczka 2014a,b; Czajka et al. 2015a). Over these 45 years, the majority of the timberline ecotone $(61 \%$ of the total timberline length) was stable or showed upward shift $(32 \%$ of the total timberline length). These results reveal the different character of the spatiotemporal dynamics in Babia Góra and Polish part of the Tatra Mountains.
The upward shift (progress) of the timberline clearly dominates in Tatras (Guzik 2008; Kaczka et al. 2015a). This may be due to the fact that, compared to the Tatras, the human impact on Babia Góra was less intense and did not lead in past to such significant and extensive transformations in the timberline ecotone.

One of the main characteristics of the timberline ecotone is the physiognomy (Holtmeier 2009). This feature includes parameters such as tree stand density, the height of the trees, species composition and the type of plant communities above the forest. Analysis of the structure of the stands, the height of the trees and their crown proportions indicates the presence of several structural types that reflect both natural factors and the influence of past human activity (Awzan et al. 1987; Szwagrzyk 2015). These features,

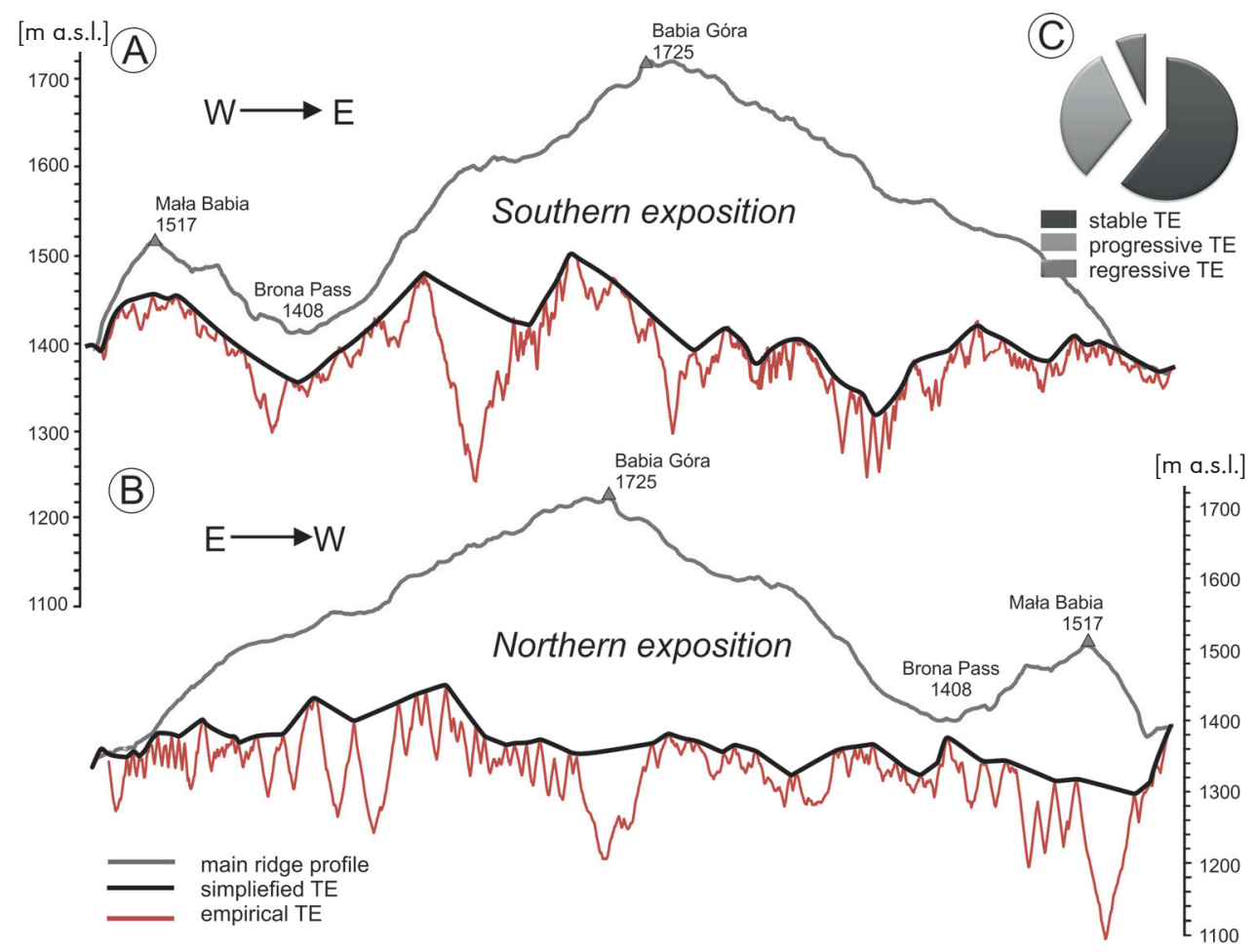

Figure. 1. Spatial diversity of the timberline of the Babia Góra Mountain on the southern (A) and northern (B) slope. The spatiotemporal dynamics of timberline during the last 45 years (1964-2009) (C) 
in conjunction with the age structure, allow the determination of the factors which contributed the most to the formation of the local timberline. The young trees are strongly limited by the thermal factor and the effect of the wind (Körner 2012). If a factor that limits the growth of trees in a given location is the sum of the temperatures in the summer months, a decrease in the height of trees at increasing elevations is accompanied by a reduction in tree stand density and an increase in the relative length of their crowns. If the most limiting factor for the growth of the trees is the regular occurrence of strong winds, especially in the winter, a decrease in the height of the trees is not accompanied by a proportional decrease in the stand density and tree crowns are relatively shorter and very asymmetric (Szwagrzyk 2015). The classic physiological type of ecotone is a gradual transition from a dense forest to an area with low vegetation (Fig. 2A). This type is common on the northern slope of the massif, which represents about $25 \%$ of the length of timberline ( 4 km). This spatial pattern is most typical for climate driven the timberline ecotone (Norton \& Schönenberger 1984; Holtmeier 2009). On the steep northern slope dense forest occurred, composed by trees with relatively narrow crowns, among which spruce trees reach a height of over 20 meters (Jaworski \& Karczmarski 1995; Zientarski 1976). At the higher altitude, the spruce trees become dwarf and mountain ash (Sorbus aucuparia) and dwarf mountain pine (Pinus mugo) become a dominant species. The transition zone between the forest and the dwarf pines is rather extensive. This type of forest boundary characterized only $25 \%$ of the
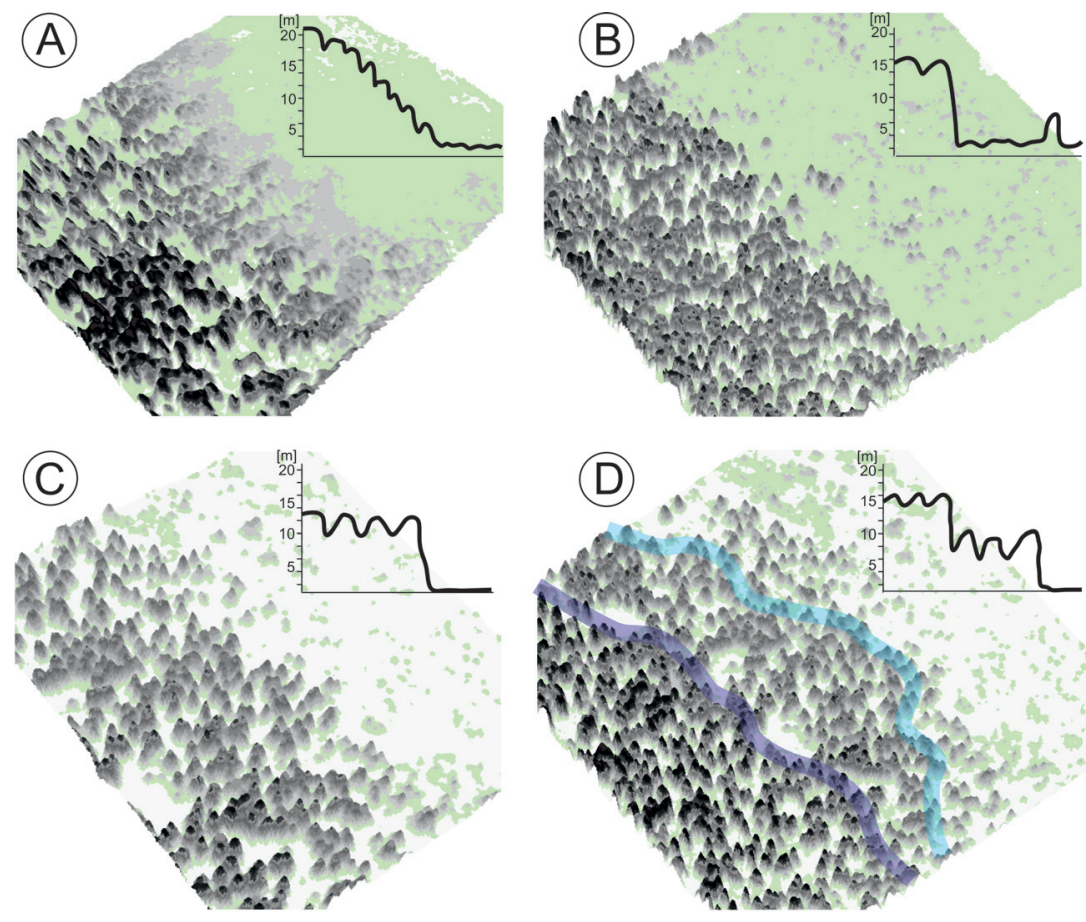

low vegetation (grasslands)

dwarf mountain pine shrubs

D location of the recent (2009) timberline

trees taller than 3 meters (spruce and mountain ash)

Figure 2. Four main physiognomic types of timberline ecotone on the Babia Góra Mt. (A-D). The graphs show the height of plant cover 
northern slope of the Babia Góra Mt. The remaining $75 \%$ of the length of the timberline on the northern slope of Babia Góra is mainly modified by avalanches (Czajka et al. 2015c) and in some locations by debris flows (Łajczak \& Migon 2007). The physiognomy of the forest typical for that part of the timberline is characterized by a dense or loose crown cover with sharp limits and some saplings in the open area (Figs. 2B and 2C). The spruce trees that grow there reach an average height of $17 \mathrm{~m}$ and they are relatively narrow with short crowns (Szwagrzyk 2015). Similarly, sharp boundaries can be found at the border of the subalpine forest with dense and high ( 2.5 m) dwarf mountain pines on the southern slope where grazing was promoted and dwarf mountain pines were eliminated (Fig. 2C). This is the only type of timberline at Babia Góra for which one of the biotic (ecological) factors plays a dominant role - competition between spruce and dwarf mountain pine. Older literature described this phenomenon as a 'struggle zone' between the two species (Myczkowski 1964) and called it a biological border (Sokołowski 1928).

In the areas of progressive timberline, characterized by upward shift, (with a total length of $12 \mathrm{~km}$ ) a more complex type of spruce forest predominates (Fig. 2D). Dense forest composed of high ( $15 \mathrm{~m})$ trees has been present at the location of the timberline since 1964 . The recent timberline has consisted of smaller trees ( 5-10 m) with a lower canopy density (0.4). The low canopy density of spruce trees allows the growth of mountain juniper (Juniperus communis L). Just above this zone individual spruce trees grow among dwarf mountain pine shrubs of low density (Holeksa et al. 2004).

\section{The influence of natural factors on the Babia Góra timberline}

The Babia Góra massif is an asymmetric ridge, its steep northern slope is generally concave and its gentler southern slope is convex (Fig. 1). Only in the western part of the massif the headwater areas of valleys reach the highest parts of the ridge and the slopes in this area mostly have a straight profile (Łajczak 2014). The $60 \mathrm{~m}$ difference between the average altitude of the timberline on the northern (1335 $\mathrm{m}$ a.s.l.) and the southern slope (1395 m a.s.I.) on Babia Góra can be linked with these conditions. The craggy parts of the northern slope of the ridge receive a smaller amount of solar energy than the southern slope. The average gradient of the slope within the timberline ecotone on the southern slope of the massif is $10^{\circ}$ smaller (average gradient $20^{\circ}$ ) and the amount of solar energy that is delivered during the growing season is $40 \%$ higher $\left(960 \mathrm{kWh} / \mathrm{m}^{2}\right)$ than on the northern slope (Czajka et al. 2015a). The timberline ecotone on the northern slope of the massif is characterized by an average gradient of $30^{\circ}$ and an amount of solar energy in the growing season equal to $666 \mathrm{kWh} / \mathrm{m}^{2}$ (Czajka et al. 2015a). The higher position of the timberline on the southern windward slope could be favored by the dominant winds from the S-W sector, thinner snow cover and earlier melting due to the lower precipitation on the slope and also due to the winnowing of snow onto the northern slope. On the southern slope there are no large snow avalanches. The lower position of the timberline on the northern slope is also due to frequent winds of the foehn type. Winnowing of snow across the main ridge results in increasing the snow accumulation on the northern slope and delays the melting of snow cover by one to two months.

The snow avalanches are main abiotic processes lowering the course of the timberline. Numerous avalanches path with a maximum length of $1000 \mathrm{~m}$ are formed only on the northern slope, while on the southern slope, only a few significantly shorter avalanche tracks can be found (Łajczak 2004; Łajczak et al. 2015). The largest lowering of the timberline that is under the influence of avalanches is observed in the western part of the northern slopes of Babia Góra. Avalanche tracks in this part of Babia Góra reach into the headwater area of the Cylowy Stream and attain a length of $800 \mathrm{~m}$ (Łajczak et al. 2015). In this area, the timberline is lowered to an altitude of $1106 \mathrm{~m}$ a.s.l., which is the minimum timberline altitude 
throughout Babia Góra (Czajka et al. 2015a,c). In this area, in the headwater area of the Cylowy Stream, snow avalanches come down concentrically along the long and straight slopes, thus causing the fragmentation of the forest. The longest snow avalanches that come down from the top of Babia Góra in the Szeroki Żleb gully reach up to $1000 \mathrm{~m}$ in length (Hudziak 1987; Łajczak 2004) and lower the timberline to about $1210 \mathrm{~m}$ a.s.l. (Fig. 1) (Czajka et al. 2015c).
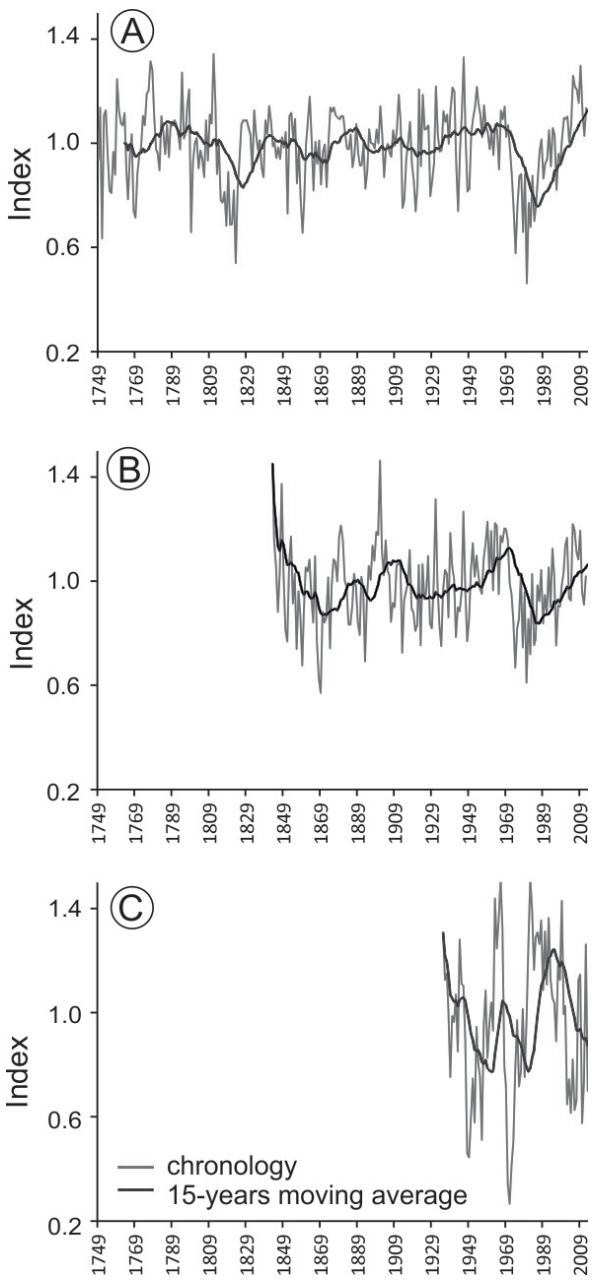

Figure 3. The standard tree-ring width chronologies of Norway spruces growing on - northern (A) and southern (B) slope and mountain ash growing on northern slope (C)
The strong influence of climate on the timberline position that has been emphasized in the literature indicates that climate change in recent decades cause a reaction in the timberline ecotone. Due to the lack of instrumental meteorological measurements at Babia Góra, it is difficult to verify the extent to which the current changes of the timberline result from global warming. The progressive character of the timberline, which is demonstrated by a $16 \mathrm{~m}$ increase in altitude between 1964-2009, is most probably the outcome of the synergy of several factors. The analysis of the climatic trend based on the gridded data CRU TS 3.1 (Harris et al. 2013) from the period between 1901 and 2013 shows a clear increase of the mean annual air temperature, the average temperature of June-July, and also growing season period. This is reflected in the positive trends in the growth of spruce from the timberline ecotone both on the southern and northern slopes (Czajka \& Kaczka 2014a; Kaczka et al. 2015b) (Fig. 3). The results of studies that were conducted in the Sudety Mountains (Głowicki 2000) and the Tatra Mountains (Niedźwiedź 2000; Żmudzka 2009, 2010), close-by mountainous regions confirm these positive trends as regional trend. Climate warming coincides with changes in land use (ceasing the grazing and logging), enhanced the effect.

The local maximum altitudes of the timberline are the effect of stable ground, lack of snow avalanches and soils that are welldeveloped and rich in nutrients. The soils of the timberline ecotone between the subalpine spruce forest and the dwarf mountain pine zone have different morphological and chemical properties. Despite their development on the slopes of a significant, up to $25^{\circ}$ gradient, they are characterized by very welldeveloped organic accumulation levels whose thickness decreases with increasing altitude. There is a clear zonation of soil positioning on Babia Góra, which is directly related to the climate and vegetation belts (Adamczyk \& Baran 1963). This relationship was seen both in the soil accumulation levels and in the deeper levels of minerals. The highest content 
of organic carbon, general nitrogen and sulfur and available phosphorus and potassium, and the highest value of the sum of the replaceable bases and sorption capacity, were determined at the levels of surface soils that had formed in the timberline ecotone. In the ecotone zone soils between the timberline and dwarf mountain pine zone the content of these components was much lower (Fig. 4). The frequent flushing of the regolith by rain delays the development of soil and forest succession on colluvial blocks on these slopes (Miechówka et al. 2004; Holeksa \& Szwagrzyk 2005). A characteristic feature of the soils that were studied was the diversity of both the physical and chemical properties (Nicia et al. 2015). The diversity is influenced by a number of factors that are not directly related to the human impact on the environment and their activities. The most important factors that affect the properties of the soils of the forest zone of the timberline include topography, slope processes, geological structure, climate and vegetation. The diversity of soil chemical properties in different altitude zones is characteristic of the soils of the mountain areas that are formed in areas with a high frequency of slope processes. It is also favored by the geology of Babia Góra which contributes to the formation of the characteristic diaphanous nature of the soil cover and, hence, to a high degree of variability within the soil profile. Along a relatively short transect (several dozen meters from the dwarf mountain pine zone to the subalpine forest), natural factors caused different pedogenic processes in the soil profiles - both podsolization and browning.

\section{The impact of anthropogenic factors on the timberline on Babia Góra}

In the literature, the reasons that cause the lowering and environmental degradation of the timberline ecotone usually include mining, grazing, deforestation, hiking, skiing, air pollution that leads to the dieback of trees, as well as the burning of forests and local fires in the forest (Midriak 1994; Mirek 1996; Motta \& Nola 2001; Boltižiar 2007; Holtmeier 2009; Slaymaker \& Embleton-Hamann 2009; Weisberg et al. 2013). Holtmeier (2009) divided the human impacts into those that had disappeared and those that were still active. For at least 600 years, the Babia Góra Mt. underwent the same types of economic use as the neighboring mountains including the Tatras (Midriak 1994; Mirek 1996; Boltižiar 2007), the Pilsko Mt. (Łajczak 2011, 2012) as well as other high mountain ranges in the Carpathians (Midriak 1994; Weisberg et al. 2013), the Karkonosze Mts. (Jahn 1985) and
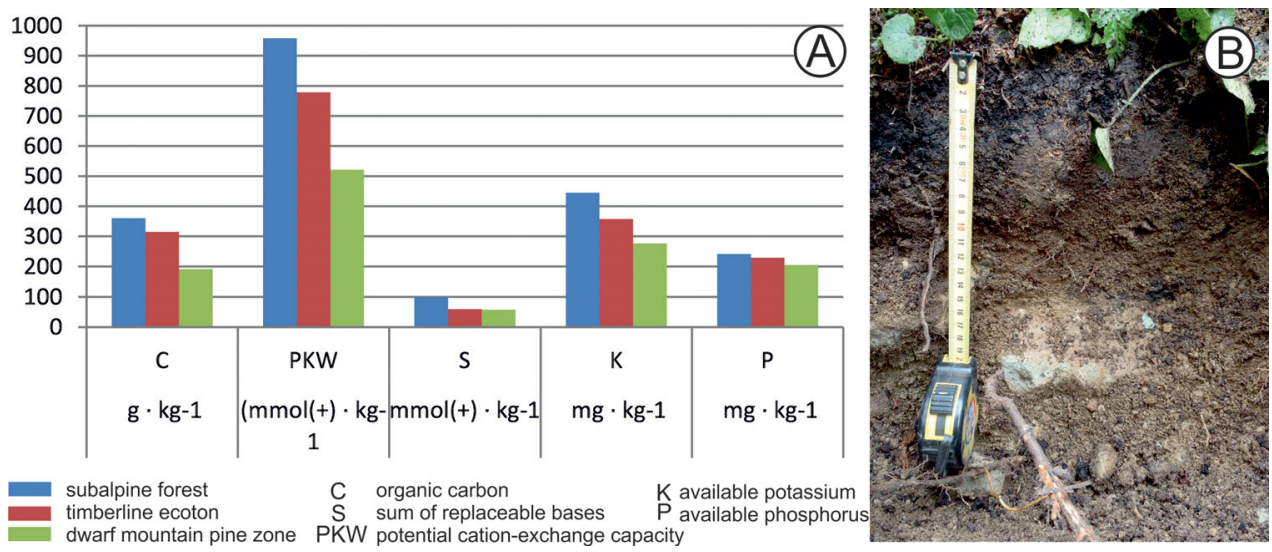

Figure 4. Selected chemical properties of the soils in three studied zones (A) Ranker with features of browning (B) - example of a typical soil for the timberline ecotone 
the Alps (Motta \& Nola 2001). Changes of the timberline on Babia Góra, like in the abovementioned mountain ranges, occurred mostly due to grazing and only locally due to forest management (Łajczak \& Lamorski 2015). One of the most visible effects of the former economic use of the natural resources of Babia Góra is the lowering of the timberline that resulted from grazing, which mostly covered the gentler southern slope (Fig. 5). This asymmetry in the lowering of the timberline was due to the accessibility of the southern slope, where grazing had developed at the beginning of the 17th century, while on the northern slope, it had developed in the 18th century. Grazing disappeared from the whole area of Babia Góra between the 20s and 70s of the twentieth century. The impact of grazing on the degradation of the timberline had both direct and indirect dimensions. The direct impact of grazing on lowering the timberline, by as much as 200 meters (vertically), can be seen in the area of the high-altitude forest clearings on the southern slope (e.g., the Hustianska, Rabčicka and Kralowa clearings), above which the forest belt that separates them from the dwarf mountain pine zone has disappeared over time.

In the former clearings, the fastest progress of forest succession has been visible over the last 50 years (Czajka, Kaczka 2014b; Czajka et al. 2015a) and is particularly clearly visible on the southern slopes of Babia Góra on the Slovakian side. Spruce trees colonize the area above the artificially lowered timberline faster than dwarf mountain pine. The past degradation of dwarf mountain pines, resulted in local activation of avalanches. This process

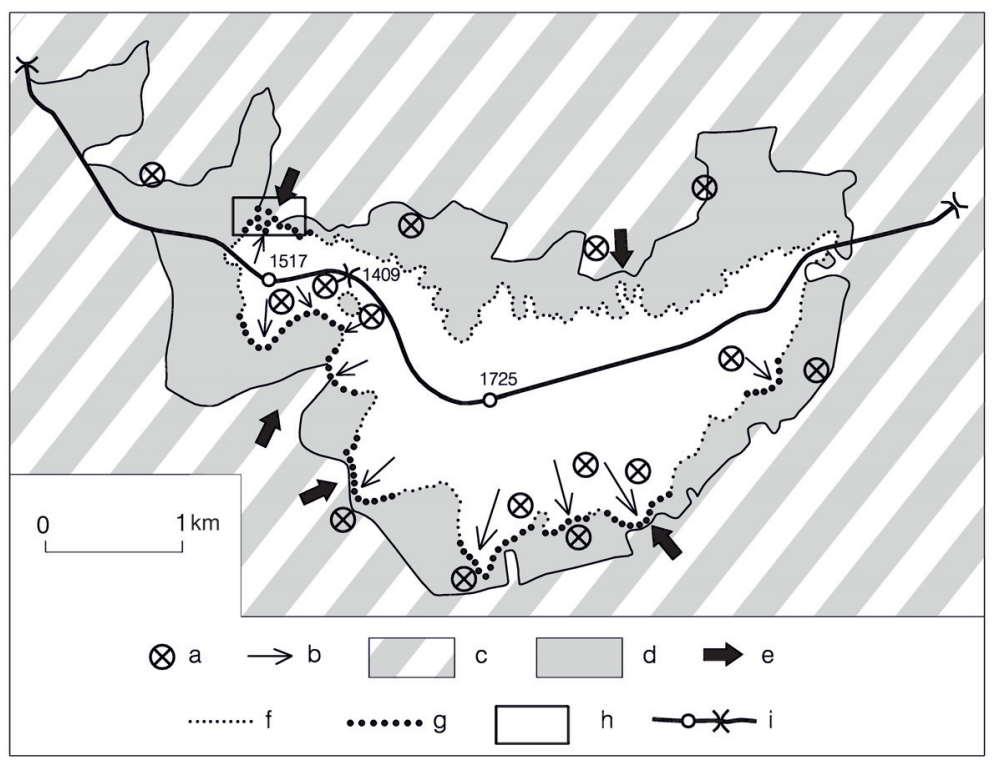

Figure 5. The location of the historically largest intensity of grazing on Mt. Babia Góra and the altitude range of forest felling, which together have led to the lowering of the timberline $a$ - the major centers of grazing, $b$ - places where lowering of the timberline occurred historically as a result of the direct and indirect impact of grazing, $c$ - areas where old trees have been cut down and replaced by a new generation of forest, $d$ - preserved old trees, e - local deforestation trends in the second and third decade of the twentieth century. The timberline: $f$ - sections of the timberline that were not changed by grazing, $g$ - sections of the timberline that were lowered by grazing, $h$ - part of the northern slope where snow avalanche activation led to the fragmentation of the forest, $i$ - the main ridge of Babia Góra with the summits - Babia Góra (1725), Mała Babia (1517) and passes - Brona Pass (1409) Lipnicka Pass and Jałowiecka Pass 
of activation of long avalanches and historic debris flows can be seen within the headwater area of the Cylowy Stream on the western part of the northern slopes of Babia Góra (Łajczak et al. 2015). The ongoing fragmentation and reduction of the sub-alpine forest and the maximum lowering of the timberline below Mała Babia can be seen in an analysis of the maps from the years 1824, 1880, 1933 and 1980 as well as by the state of the slope that is shown in the watercolor painting by Eljasz-Radzikowski, which was painted in 1860 (Łajczak \& Lamorski 2015).

By comparing Babia Góra with others, even the neighboring mountainous areas, it can be concluded that under-investment in the tourist base protected the massif from further degradation of the timberline which could have been caused by the development of a ski center in the Tatras (Mirek 1996) or Pilsko (Łajczak 2011). The creation of nature reserves in 1928 and in 1933 and of a national park in 1954 in the Polish part of the massif and of nature reserves in 1926 and in 1979 in the Slovakian part of the massif, resulted in the removal of grazing and logging from Babia Góra. The ongoing recovery of forest, timberline and alpine environment has not yet been fully completed (Fig. 6).

\section{Summary}

The timberline on Babia Góra Mt. runs at an altitude of 1106 to $1508 \mathrm{~m}$ a.s.l. The average altitude of the timberline on the southern slope runs $60 \mathrm{~m}$ higher than on the northern slope, mainly due to the higher amount of solar energy (40\%) during the growing season on the southern slope, nutrient-rich soils, and slope stability. The lower position of the timberline on the northern slope is due to the lower amount of solar radiation, frequent foehn winds, a thicker and longer lasting snow cover, snow avalanches, and locally debris flows and landslides which result in less favorable edaphic conditions.
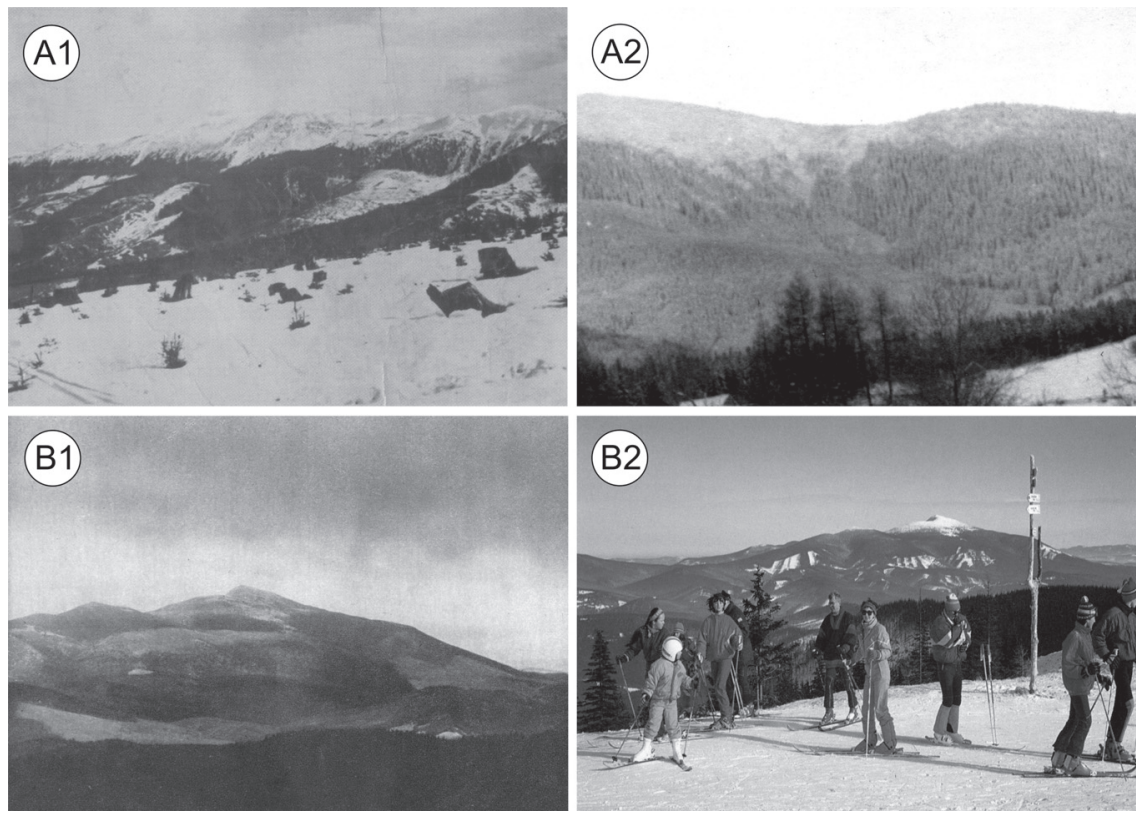

Figure 6. Progression of the timberline on Babia Góra after the cessation of grazing and regeneration of forest in areas affected by large-scale felling of old forest

A - Northern slope of Babia Góra (1 - situation in the 1920s, 2 - situation in the 1960s), B - the western part of the southern slope within Slovakia (1 - situation in the 1920s, 2 - current situation, view from Pilsko Mt.) 


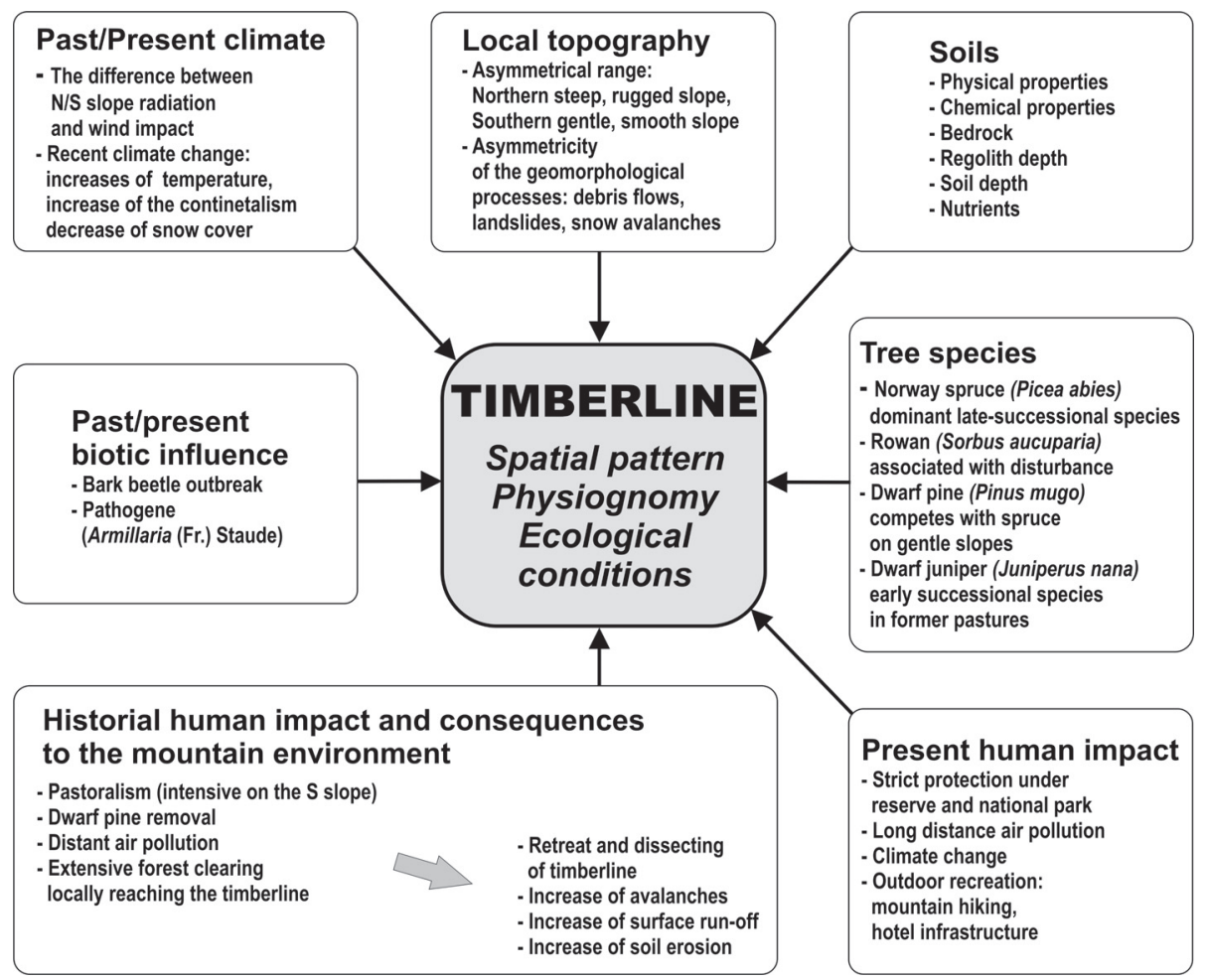

Figure 7. The functional model of the timberline on Babia Góra Mt. as a result of the temporally and spatially variable effects of natural and anthropogenic factors

Source: Adaptation of the Holtmeier model (2009)

The main feature of the timberline in Babia Góra dynamics in the last 50 years is its stability on the northern slope and its progress in altitude on the southern slope. This is the result of its history and natural conditions (Fig. 7). Originating in a geological structure, the asymmetric shape of the ridge of the Babia Góra Mt. created consequences for most of the components of the environment of the timberline. Both of the slopes, despite their differences, were covered by Carpathian Forest until the middle of the 19th century. The attractiveness of the southern slope of the massif has led to intensive use, mainly grazing and logging. The northern slope, which is not so easily accessible, was subject to large-scale economic activity much later. Therefore one of the most visible effects of the economic use of the natural resources of the Babia
Góra massif is the lowering of the timberline on southern slope. The initiation of this process dates back to the beginning of the 17th century whereas on the northern slope the same activity started in the 18th century. The establishing of the nature reserves (1926, 1928, 1933 and 1979) and national park in Polish part of the massif (1954) resulted in the cessation of economic activity on Babia Góra and allow the regeneration of the dwarf mountain pine and the timberline.

Recent changes within the timberline ecotone include ongoing spontaneous regeneration and adaptation to the conditions that were created by indirect human impact for which the main factors are global warming and air pollution. These processes are only disturbed by extreme events like windstorms, or biological processes (like outbreaks of bark beetle). 


\section{Acknowledgements}

The Authors would like to thank the Babiogórski National Park for the access to archival photos and data of the Airborne Laser Scanning.

The work has been conducted as part of the research project of the Polish National Science Centre NN 306 070640, entitled Natural and

\section{References}

Adamczyk B., Baran S., 1963. The soils of Babia Góra Mt. [in:] W. Szafer (ed.), Babiogórski Park Narodowy, Kraków: Zakład Ochrony Przyrody PAN, pp. 89-107.

AleXandrowicz S.W., 2004. Outlines of geology of the Babia Góra range [in:] B.W. Wołoszyn, A. Jaworski, J. Szwagrzyk (eds.), Babiogórski Park Narodowy: Monografia Przyrodnicza, Kraków: Wydawnictwo i Drukarnia Towarzystwa Słowaków w Polsce, pp. 527-600.

Awzan L., Kasprowicz M., Węglarski K., 1987. Zmienność górnoreglowego boru karpackiego oraz morfologia świerka przy górnej granicy lasu na pótnocnych zboczach Babiej Góry. Rocznik Dendrologiczny, 37, pp. 5-24.

Ayres M.P., Lombardero M.J., 2000. Assessing the consequences of global change for forest disturbance from herbivores and pathogens. Science of The Total Environment, vol. 262, no. 3, pp. 263-286

BeBI P., Kułakowski D., Rixen C., 2009. Snow avalanche disturbances in forest ecosystems: State of research and implications for management. Forest Ecology and Management, vol. 257, no. 9, pp. 1883-1892.

BoltǏlAR M., 2007. Štruktúra vysokohorskej krajiny Tatier. Nitra: Fakulta prírodných vied Univerzity Konštantína Filozofa.

Brown D.G., 1994. Predicting vegetation types at treeline using topography and biophysical disturbances. Journal of Vegetation Sciences, vol. 5, no. 5, pp. 641-656.

CZAJKA B., KACZKA R.J., 2014a. Stability of natural and modified timberline at Babia Gora Mt., Carpathians. Tree Rings in Archaeology. Climatology and Ecology, 12, pp. 46-53. anthropogenic conditioning of the occurrence of the timberline on Babia Góra Mountain, and its dynamics over the last 200 years.

Editors' note:

Unless otherwise stated, the sources of tables and figures are the authors' on the basis of their own research.

CZAKA B., KACZKA R.J., 2014b. Dendrochronologiczna charakterystyka górnej granicy lasu na Babiej Górze w strefie jej progresu. Studia i Materiały Centrum Edukacji Przyrodniczo-Leśnej w Rogowie, 16, pp. 42-52.

CZAJKa B., ŁAJCZAK A., KaCZKA R.J., 2015a. The $d y$ namics of the timberline ecotone on the asymmetric ridge of the Babia Góra Massif, Western Carpathians. Geographia Polonica, vol. 88, no. 2, pp. 85-102.

CZAJKa B., Łauczak A., KaczKa R.J., 2015b. Geographical characteristics of the timberline in the Carpathians. Geographia Polonica, vol. 88, no. 2, pp. 35-54.

CZAKA B., ŁAICZAK A., KACZKA R.J., 2015c. The influence of snow avalanches on the timberline in the Babia Góra Massif, Western Carpathians. Geographia Polonica, vol. 88, no. 2, pp. 147-161.

Dullinger S., Dirnböck T., Grabherr G., 2004. Modelling climate change-driventimberline shifts: Relative effects of temperature increase, dispersal and invasibility. Journal of Ecology, vol. 92, no. 2, pp. 241-252.

GŁOWICKI B., 2000. 20th century variability to daily maxima and minima of air temperature in the Sudetic Mountains. Geographica Polonica, vol. 73, no. 2, pp. 111-116.

GuzIK M., 2008. Analiza wpływu czynników naturalnych $i$ antropogenicznych na kształtowanie się zasięgu lasu i kosodrzewiny w Tatrach. Kraków: Uniwersytet Rolniczy im. Hugona Kołłątaja. Wydział Leśny. Katedra Botaniki Leśnej i Ochrony Przyrody [PhD thesis].

HARRIS I., JONES P.D., OsbORN T.J., LISTER D.H., 2013. Updated high-resolution grids of monthly climatic observations the CRU TS3. 10 Dataset. International Journal of Climatology, vol. 34, no. 3, pp. 623-642. 
Hess M., 1965. Piętra klimatyczne w Polskich Karpatach Zachodnich. Zeszyty Naukowe UJ. Prace Geograficzne, 11, Kraków: Uniwersytet Jagielloński.

Holeksa J., Szwagrzyk J., Musiatowicz W., PaRUSEL J., 2004. Struktura i dynamika lasów Babiogórskiego Parku Narodowego [in:] B.W. Wołoszyn, A. Jaworski, J. Szwagrzyk (eds.), Babiogórski Park Narodowy: Monografia Przyrodnicza, Kraków: Wydawnictwo i Drukarnia Towarzystwa Słowaków w Polsce, pp. 527-598.

Holeksa J., SzWagrzYK J., 2005. Szata Roślinna [in:] D. Ptaszycka-Jackowska (ed.), Światy Babiej Góry, Zawoja: Babiogórski Park Narodowy, Grafikon, pp. 43-93.

Holtmeler F.K., 2009. Mountain timberlines: Ecology, patchiness, and dynamics. Advances in Global Change Research, 36, Dordrecht: Springer.

HudzIAK E., 1987. Lawiny śnieżne na Babiej Górze. Prace Babiogórskie, 7, pp. 96-98.

IPCC, 2013. Climate change 2013: The physical science basis. Contribution of Working Group I to the Fifth Assessment Report of the Intergovernmental Panel on Climate Change. Cambridge-New York: Cambridge University Press.

JAHN A., (ed.) 1985. Karkonosze polskie. Wrocław: Zakład Narodowy im. Ossolińskich.

JAWORSKI A., KaRCZMARSKI J., 1995. Budowa, struktura, dynamika i możliwości produkcyjne górnoreglowych borów świerkowych w Babiogórskim Parku Narodowym. Acta Agraria et Silvestria. Series Silvestris, 33, pp. 75-113.

JoDŁOWSKI M., 2007. Górna granica kosodrzewiny w Tatrach, na Babiej Górze i w Karkonoszach: Struktura i dynamika ekotonu. Kraków: Instytut Geografii i Gospodarki Przestrzennej Uniwersytetu Jagiellońskiego.

KaczKa R.J., Lempa M., CZAjka B. , Janecka K., RĄCZKOWSKA Z., HREŠKo J., BugAR G., 2015a. The recent timberline changes in the Tatra Mountains: A case study of the Mengusovská Valley (Slovakia) and the Rybi Potok Valley (Poland). Geographia Polonica, vol. 88, no. 2, pp. 71-83.

KACZKA R.J., CZAJKA B., ŁAJCZAK A., 2015b. The treering growth responses to climate in the timberline ecotone of Babia Góra Mountain. Geographia Polonica, vol. 88, no. 2, pp. 163-176.

Kotarba A., Starkel L., 1972. Holocen morphogenetic altitudinal zones in the Carpathians.
Studia Geomorphologica Carpatho-Balcanica, 6, pp. 21-35.

KöRNER C., 2012. Alpine treelines: Functional ecology of the global high elevation tree limits. Basel: Springer.

KULLMAN L. 2002. Rapid recent range-marin rise of tree and shrub species in the Swedish Scandes. Journal of Ecology, vol. 90, no. 1, pp. 68-76.

Łauczak A., 2004. Pokrywa Śnieżna Babiej Góry [in:] B.W. Wołoszyn, A. Jaworski, J. Szwagrzyk (eds.), Babiogórski Park Narodowy: Monografia Przyrodnicza, Kraków: Wydawnictwo i Drukarnia Towarzystwa Słowaków w Polsce, pp. 179-196.

Łauczak A., Migoń P., 2007. The 2002 debris flow in the Babia Góra massif - implications for the interpretation of mountainous geomorphic systems. Studia Geomorphologica Carpatho-Balcanica., 41, pp. 97-116.

ŁAJCZAK A., 2011. Masyw Pilska w Beskidzie Żywieckim: Przyroda i człowiek. Kraków: Instytut Botaniki im. W. Szafera.

ŁAJCZAK A., 2012. Ocena antropogenicznych zmian w rzeźbie masywu Pilska i sqsiadujacego obszaru [in:] A. Łajczak (ed.), Antropopresja w wybranych strefach morfoklimatycznych - zapis zmian w rzeźbie i osadach, Prace Wydziału Nauk o Ziemi, 77, Sosnowiec: Wydział Nauk o Ziemi Uniwersytetu Śląskiego, pp. 242-253.

ŁAJCZAK A., 2014. Relief development of the Babia Góra massif, Western Carpathians. Questiones Geographicae, vol. 33, no. 1, pp. 89-106.

ŁaJCZAK A., CZAJKA B., KaCZKA J.R., 2014. The new features of landslide relief discovered using LiDAR - case study from Babia Góra massif, Western Carpathian Mountains. Questiones Geographicae, vol. 33, no. 3, pp. 77-88.

ŁAJCZAK A., LAMORSKI T. 2015. Economic use of the Babia Góra massif and the assessment of anthropogenic changes in the course of the timberline. Geographia Polonica, vol. 88, no. 2, pp. 115-138.

Łauczak A., CZajka B., KaczKa R.J., 2015. Development of touristic infrastructure at Babia Góra Mt. (Western Carpathians) in conditions of intensive slope processes hazard. Prace Geograficzne IGiGP UJ, 136, Kraków: Instytut Geografii i Gospodarki Przestrzennej. Uniwersytet Jagielloński.

MiDRIAK R., 1994. Geoekólogia vysokých pohori Slovenska. Zvolen: Technická univerzita. 
MiechóWka A., Niemyska-Łukaszuk J., Zaleski T., MaZurek R., 2004. Gleby Babiogórskiego Parku Narodowego [in:] B.W. Wołoszyn, A. Jaworski, J. Szwagrzyk (eds.), Babiogórski Park Narodowy: Monografia Przyrodnicza, Kraków: Wydawnictwo i Drukarnia Towarzystwa Słowaków w Polsce, pp. 197-211.

MIREK Z., 1996. Antropogeniczne zagrożenia i przekształcenia środowiska przyrodniczego [in:] Z. Mirek (ed.), Przyroda Tatrzańskiego Parku Narodowego, Kraków-Zakopane: Wydawnictwo Tatrzańskiego Parku Narodowego, pp. 595-617.

MotTA R., Nola P., 2001. Growth trends and dynamics in sub-alpine forest stands in the Varaita Valley (Piedmont, Italy) and their relationship with human activities and global change. Journal of Vegetation Science, vol. 12, no. 2, pp. 219-230.

MrCZKOWSKI S., 1964. Struktura i ekologia zespołu świerka Piceetum tatricum u górnej granicy zasięgu w Tatrzańskim Parku Narodowym w okolicach Stawów Gqusienicowych i Pańszczycy. Ochrona Przyrody, 30, Kraków: Zakład Ochrony Przyrody, pp. 51-105.

NiCIA P., ZADROŻNY P., CZAJKa B., 2015. The diversity of soils of the upper forest line, transition, and mountain pine zones in the Babia Góra massif. Geographia Polonica, vol. 88, no. 2, pp. 139-145.

NiedźWIedź T., 2000. Zmienność temperatury powietrza i opadów w Tatrach w ostatnich 50 latach [in:] M. Bac-Moszaszwili (ed.), Współczesne przemiany środowiska przyrodniczego Tatr: Zakopane, 12-14 października 2000. Kraków: Polskie Towarzystwo Przyjaciół Nauk o Ziemi, pp. 37-38.

Norton D.A., Schönenberger W., 1984. The growth forms and ecology of Nothofagus solandri at the alpine timberline, Craigieburn Range, New Zealand. Arctic and Alpine Research, vol. 16, no. 3, pp. 361-370.

ObręBSKa-Starkel B., 2004. Klimat Masywu Babiej Góry [in:] B.W. Wołoszyn, A. Jaworski, J. Szwagrzyk (eds.). Babiogórski Park Narodowy: Monografia Przyrodnicza, Kraków: Wydawnictwo i Drukarnia Towarzystwa Słowaków w Polsce, pp. 137-151.

Parusel J., Kasprowicz M., Holeksa J., 2004. Forest and brushwood communities in the Babiogórski National Park [in:] B.W. Wołoszyn, A. Jaworski, J. Szwagrzyk (eds.). Babiogórski Park Narodowy: Monografia Przyrodnicza, Kraków: Wydawnictwo i Drukarnia Towarzystwa Słowaków w Polsce, pp. 429-475.

Plesník P., 1971. Horná hranica lesa vo Vysokých a Belanských Tatrách. Bratislava: Vydavatelstvo Slovenskej Akadémie Vied.

RACZKOWSKA Z., 2006. Recent geomorphic hazards in the Tatra Mountains. Studia Geomorphologica Carpatho-Balcanica, 40, pp. 45-60.

SitKo I., Troll M., 2008. Timberline changes in relation to summer farming in the Western Chornohora (Ukrainian Carpathians). Mountain Research and Development, vol. 28, no. 3, pp. 263-271.

Slaymaker O., Embleton-Hamman Ch., 2009. Mountains [in:] O. Slaymaker, T. Spencer, C. EmbletonHamman (eds.), Geomorphology and global environmental changes, Cambridge: Cambridge University Press, pp. 37-70.

Smith W.K., Germino M. J., Hancock T.E., JohnSON D.M., 2003. Another perspective on altitudinal limits of alpine timberlines. Tree Physiology vol. 23, no. 16, pp. 1101-1112.

SokOŁOWSKI M., 1928. O górnej granicy lasu w Tatrach. Kraków: Zakłady Kórnickie.

SZWAGRZYK J., 2015. Structure of the forest ecotone in the Babia Góra Massif, Western Carpathians. Geographia Polonica, vol. 88, no. 2, pp. 103-113.

TranquiluINI W., 1979. Physiological ecology of the alpine timberline. Tree existence at high altitudes with special references to the European Alps. Ecological Studies, 31, Berlin-New York: Springer-Verlag.

TROLL C., 1973. The upper timberline in different climatic zones. Arctic and Alpine Research, vol. 5, no. 3, pp. A3-A18.

Walsh S., Butler D., Thomas A., Malanson G., 1994. Influence of snow patterns and snow avalanches on the alpine treeline ecotone. Journal of Vegetation Science, vol. 5, no. 5, pp. 657-672.

Weisberg P.J., Shandra O., Becker M.E., 2013. Landscape influences on recent timberline shifts in the Carpathian Mountains: Abiotic influences modulate effects of land-use change. Arctic, Antarctic, and Alpine Research, vol. 45, no. 3, pp. 404-414.

ZIENTARSKI J., 1976. Wpływ wzniesienia nad poziomem morza na zagęszczenie i ukształtowanie górnoreglowych borów świerkowych 
w Babiogórskim Parku Narodowym. Prace Komisji Nauk Rolniczych i Komisji Nauk Leśnych, 42, Poznań: Poznańskie Towarzystwo Przyjaciół Nauk, pp. 137-149.

ZientARSKI J., 1985. Wpływ wzniesienia oraz wielkości masywu górskiego na kształtowanie się górnej granicy lasu w Polsce. Poznań: Akademia Rolnicza [PhD thesis].
ŻMUDZKA E., 2009. Changes of thermal conditions in the Polish Tatra Mountains. Landform Analysis, 10, pp. 140-146.

ŻMUDZKA E., 2010. Sygnat globalnego ocieplenia w Tatrach. Tatry: TPN, vol. 31, no. 1, pp. 44-47.
(C) R.J. Kaczka • B. Czajka • A. Łajczak • J. Szwagrzyk • P. Nicia

(C) Geographia Polonica

(C) Institute of Geography and Spatial Organization

Polish Academy of Sciences - Warsaw • 2015
Article first received $\bullet$ January 2015 Article accepted - April 2015 
http://rcin.org.pl 